\title{
Sickness absence of lead workers and controls
}

\author{
H. S. SHANNON ${ }^{1}, M$. K. WILLIAMS ${ }^{2}$, and E. KING ${ }^{3}$ \\ TUC Centenary Institute of Occupational Health, London School of Hygiene and Tropical \\ Medicine, London WC1E 7HTㄹ, Chloride Automotive Batteries Limited, Dagenham Dock ${ }^{2}$, \\ and the National Occupational Hygiene Service Limited, Manchester ${ }^{3}$
}

\begin{abstract}
Shannon, H. S., Williams, M. K., and King, E. (1976). British Journal of Industrial Medicine, 33, 236-242. Sickness absence of lead workers and controls. Certificated sickness rates and levels of lead exposure of 955 men whoworked in a lead accumulator factory during a period of seven years (1965-72) were examined. The men were divided by department into four exposure groups; a second division into three groups was made, based on the mean of each man's blood lead measurements during the study period. Absences showed no age pattern, but men who left during the seven years of observation (ex-workers) had had a higher absence rate (842 spells/1000 man years) than those still employed in 1972 (535 spells/1000 man years). There was no significant difference in absence rates or lengths of absences between differently exposed departments either for all causes or for a selected group of potentially lead-induced causes. However, the proportion of potentially lead-induced absences was significantly higher in ex-workers $(12.2 \%)$ than in current workers $(7 \cdot 4 \%)$. Similar analysis showed no significant differences in absence rates of men with different blood lead levels. It was concluded that higher levels of lead exposure did not seem to be associated with higher rates of absence or longer absences either for all causes of absence combined or for those causes which might be attributable to lead.
\end{abstract}

It has been known since antiquity that lead poisoning can result in death. Long-term sequelae include chronic nephropathy and neuropathy in adults, and chronic encephalopathy in children (National Academy of Sciences, 1972; Waldron and Stöfen, 1974). The mortality associated with more moderate levels of chronic lead exposure was investigated in male adults at an electric accumulator factory by Dingwall-Fordyce and Lane (1963). They found that deaths from cerebrovascular disease were commoner among those pensioners who had worked in the more highly exposed lead departments, but the numbers available were small. In a follow-up study in the same factory, Malcolm (1971) found little difference between the mortality of exposed men and controls and he attributed this to improved industrial hygiene. In a recent study on the mortality of electric accumulator and lead smelter workers in the USA, Tabershaw-Cooper Associates Inc. (1974) obtained 1267 death certificates and found no association between lead exposure and either cerebrovascular accidents or hypertensive heart disease, but deaths attributed to 'other hypertensive disease' and to 'chronic nephritis and other renal sclerosis' were in excess in both smelter and battery plant workers. The blood lead and urinary lead data available suggested that workers' lead exposure had 'greatly exceeded currently recommended standards'.

There appear to have been no controlled studies on the morbidity of lead workers. In order to determine whether currently accepted levels of industrial exposure are sufficient to prevent the occurrence of subclinical sickness absence due to lead, the sickness absence of workers in an electric accumulator factory has been investigated. 


\section{The factory}

The factory contains a small lead smelter (three reverberatory furnaces) and refiner departments making battery separators and other plastics, and service departments in addition to departments making electric accumulators. There is a small interchange of labour between departments as manufacturing requirements vary.

Routine estimations of blood lead were introduced in 1965. Estimations are made with a frequency which depends on the degree and stability of the lead exposure. Recently, the frequency of routine estimation has varied between zero, in the plastics and low lead departments, and quarterly, in the smelter men and in those men in other departments whose previous blood leads exceeded 2.90 $\mu \mathrm{mol} / \mathrm{l}(60 \mu \mathrm{g} / 100 \mathrm{ml})$. The company's medical policy has been to transfer men with blood lead levels exceeding $3.86 \mu \mathrm{mol} / 1(80 \mu \mathrm{g} / 100 \mathrm{ml})$ to other work unless the exposure could be reduced satisfactorily by other means. In the period studied (1 May 1965 to 30 April 1972) 13 men were transferred to other work on 18 occasions. In 1965 and again in 1966 one man was transferred because he suffered falls in haemoglobin attributed to lead.

All employees absent sick for more than three days are required to supply. National Insurance medical certificates from their doctors for the period of absence. The diagnosis on each certificate and the length of absence is recorded by the personnel department.

\section{Methods}

Routine blood lead estimations were started in 1965 , so the records of all weekly-paid men who were employed in the factory between 1 May 1965 and 30 April 1972 inclusive, were studied. The data obtained for each employee were: name, date of birth, dates of entering and leaving employment, the dates and causes of certificated sickness absence, the dates of entering and leaving every department worked in, and the dates and values of all blood lead estimations.

The cause of absence was taken to be the diagnosis given on the first National Insurance medical certificate, except where this was vague, for example "hospitalization', when a subsequent diagnosis was used. The diagnosis from the first medical certificate, although possibly less accurate than subsequent ones, was taken to ensure that the diagnosis used was that of the primary disease rather than of a complication. The causes were coded using the International Classification of Diseases numbers (World Health Organization, 1967) and the number of working days lost was calculated.

The departments were grouped into four categories of exposure as follows:

High - forming, furnace, pasting, plate-cutting, ball mill

Mixed - assembly, machine shop

Low - casting, transport and loading, charg- ing, inspection, warehouse, packing and despatch

No exposure - general services, outdoor erection, plastics departments, boiler house.

The mixed exposure category consisted of departments in which some men were exposed to lead, while others were not.

In addition, the mean blood lead value was calculated for each man, and three groups were formed:

1. those with no blood lead measured

2. those whose mean blood lead was less than $2 \cdot 41$ $\mu \mathrm{mol} / 1(50 \mu \mathrm{g} / 100 \mathrm{ml})$

3. those whose mean blood lead was greater than or equal to $50 \mu \mathrm{g} / 100 \mathrm{ml}$.

All blood lead estimations had been carried out under the direction of one of us (EK) using a dithizone method which has been described briefly (Williams, King, and Walford, 1969), and in detail (Hoschek and Schittke, 1973). The method and laboratory have been validated by their performance as Institute 25 in the Hoschek interlaboratory comparison (Hoschek and Schittke, 1973) and as Laboratory 52 in the Queen Elizabeth National Quality Control Scheme (blood lead trial) organized by Professor T. P. Whitehead, Queen Elizabeth Medical Centre, Birmingham. Some batches of blood lead had been believed in 1965 to be contaminated and were rejected. These were excluded from the calculations.

The men were divided into two groups: workers and ex-workers. Workers were those still working in the factory on 30 April 1972, and ex-workers were those who had left at any time during the survey period.

The man years at risk during the survey period for workers and ex-workers in each exposure category were calculated in nine five-year age groups. These age groups were then reduced to two, 20-39 and 40-64, to obtain approximately equal lengths of exposure in each group (Table 2). Absences were also grouped by age and exposure category and mean blood lead levels for both workers and ex-workers and then classified by cause into various broad diagnostic groups.

In addition, in order to investigate whether the symptoms of lead poisoning had been misdiagnosed, the ICD numbers of the symptoms of lead poisoning described by Lane et al. (1968) were obtained (Table 1) and a group of 'potentially lead-induced absences' was formed by combining all absences with these ICD numbers.

\section{Results}

There were 615 workers and 340 ex-workers. Table 2 shows their mean blood lead and the number of man years at risk by age group and exposure. Workers' man years at risk were 3995 and ex-workers were 840. Although the non-exposed group has a higher mean blood lead level than the low-exposure group, the former had a relatively small number of readings. Indeed, the mean blood lead for men in non-exposed departments is $1.54 \mu \mathrm{mol} / 1(32 \mu \mathrm{g} / 100$ $\mathrm{ml}$ ) if the blood lead values of men suspended from high exposure departments are omitted. The values show that the groupings of departments by exposure were satisfactory. The mean blood lead for all workers, $2.67 \mu \mathrm{mol} / 1(55.4 \mu \mathrm{g} / 100 \mathrm{ml})(\mathrm{SD}=0.89)$ 
TABLE 1

Symptoms of LEAD Poisoning AND ICD Numbers Allotted

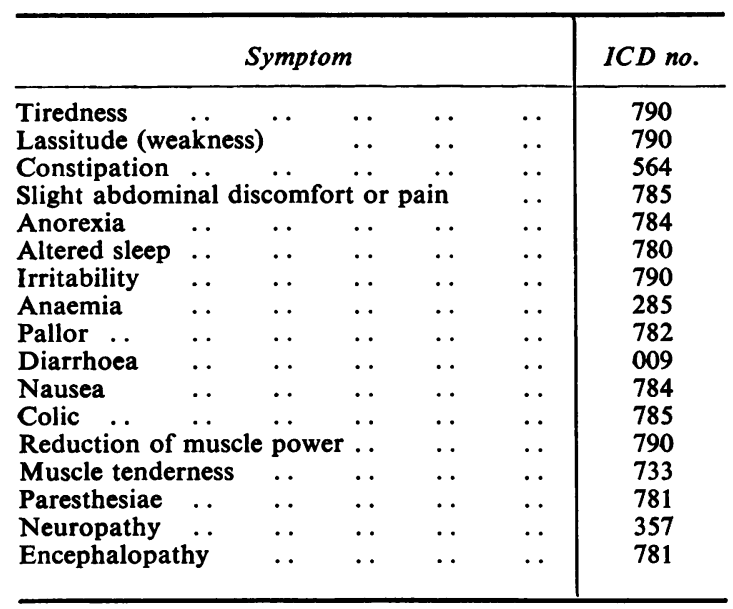

was very similar to that for ex-workers $2.69 \mu \mathrm{mol} / 1$ $(55.8 \mu \mathrm{g} / 100 \mathrm{ml})(\mathrm{SD}=1.00)$.

The numbers of spells of absence by diagnostic group and age for workers and ex-workers are shown in Table 3. The absence rates were higher for ex-workers in nearly every diagnostic category. The overall rates were not significantly different for the two age groups in either workers or ex-workers, although there were differences in individual diagnostic groups. For example, the absence rates in older men were higher for musculo-skeletal diseases and for diseases of the circulatory system, but lower for accidents. The overall difference in the rates for workers and ex-workers was highly significant $\left(\chi_{(1)}^{2}\right.$ $=111.1, \mathrm{P}<0.001)$.

The rates of all absences by exposure category were compared for workers and ex-workers (Table
4). The rates are higher in the lower exposure groups; the differences for workers are highly significant $\left(\chi_{(3)}^{2}=71 \cdot 2, \mathrm{P}<0.001\right)$ and for exworkers are significant $(\chi \underset{(3)}{2}=8.81, \mathrm{P}<0.05)$.

A similar comparison was made for absence rates from potentially lead-induced causes by exposure category for workers and ex-workers (Table 5). For workers the rates in the less exposed groups were higher than in the more exposed groups. Indeed the differences were highly significant $\left(\chi_{(3)}^{2}=12 \cdot 8, \mathrm{P}<\right.$ 0.01 ). The opposite pattern was found for exworkers, although the relatively high rate for unexposed men means that the pattern is not consistent.

Thus, in general, there was a higher absence rate in lower exposed groups both for all causes and for the potentially lead-induced causes. This could have been because fitter men were selected for high exposure departments. To take some account of this the percentages of all absences due to the potentially lead-induced causes were calculated (Table 6). Thus even though the higher exposure groups had lower absence rates, a relative excess of absences due to potentially lead-induced causes would be apparent.

For workers, the percentage of absences due to the potentially lead-induced causes decreased with exposure, but this was not significant $\left(\chi_{(3)}^{2}=2 \cdot 1\right)$. The opposite occurred for ex-workers: grouping the high and mixed exposure groups together and the low and no exposure groups together, the percentage for the former was significantly higher $(\chi \underset{(1)}{2}=6.97$, $P<0.01$ ).

Apart from the low exposure group, ex-workers had relatively more absences due to the potentially lead-induced causes than did the workers. The overall percentages of all absences due to these causes

TABLE 2

Man Years at Risk by Age and Mean Blood Lead, by Exposure LeVel for 615 WORKERS AND 340 EX-WORKERS

\begin{tabular}{|c|c|c|c|c|c|c|c|}
\hline \multirow{3}{*}{ Exposure } & \multirow{3}{*}{$\begin{array}{c}\text { No. of } \\
\text { observations }\end{array}$} & \multicolumn{2}{|c|}{ Mean blood lead $\pm S D$} & \multicolumn{4}{|c|}{ Man years } \\
\hline & & \multirow[t]{2}{*}{$(\mu g / 100 \mathrm{ml})$} & \multirow[t]{2}{*}{$(\mu \mathrm{mol} / \mathrm{l})$} & \multicolumn{2}{|c|}{ Workers age } & \multicolumn{2}{|c|}{ Ex-workers age } \\
\hline & & & & $20-39$ & $40-64$ & $20-39$ & $40-64$ \\
\hline $\begin{array}{ll}\text { High } & \ldots \\
\text { Mixed } & \ldots \\
\text { Low } & \ldots \\
\text { None } & \cdots\end{array}$ & $\begin{array}{r}2246 \\
746 \\
378 \\
52\end{array}$ & $\begin{array}{l}59.8 \pm 18.0 \\
49.8 \pm 17.9 \\
42.1 \pm 15.4 \\
45.2 \pm 15.4\end{array}$ & $\begin{array}{l}2.89 \pm 0.87 \\
2.41 \pm 0.86 \\
2.03 \pm 0.74 \\
2.18 \pm 0.74\end{array}$ & $\begin{array}{l}377 \\
774 \\
338 \\
362\end{array}$ & $\begin{array}{l}342 \\
801 \\
554 \\
447\end{array}$ & $\begin{array}{r}59 \\
150 \\
72 \\
117\end{array}$ & $\begin{array}{r}54 \\
113 \\
161 \\
114\end{array}$ \\
\hline Total & 3422 & $55.4 \pm 18.8$ & $2.68 \pm 0.91$ & 1851 & 2144 & 398 & 442 \\
\hline Grand total & - & 一 & - & \multicolumn{2}{|c|}{3995} & \multicolumn{2}{|c|}{840} \\
\hline
\end{tabular}


TABLE 3

Rates of Absence (Spells/1000 Man Years) by Diagnostic Group and Age for WORKERS AND EX-WORKERS

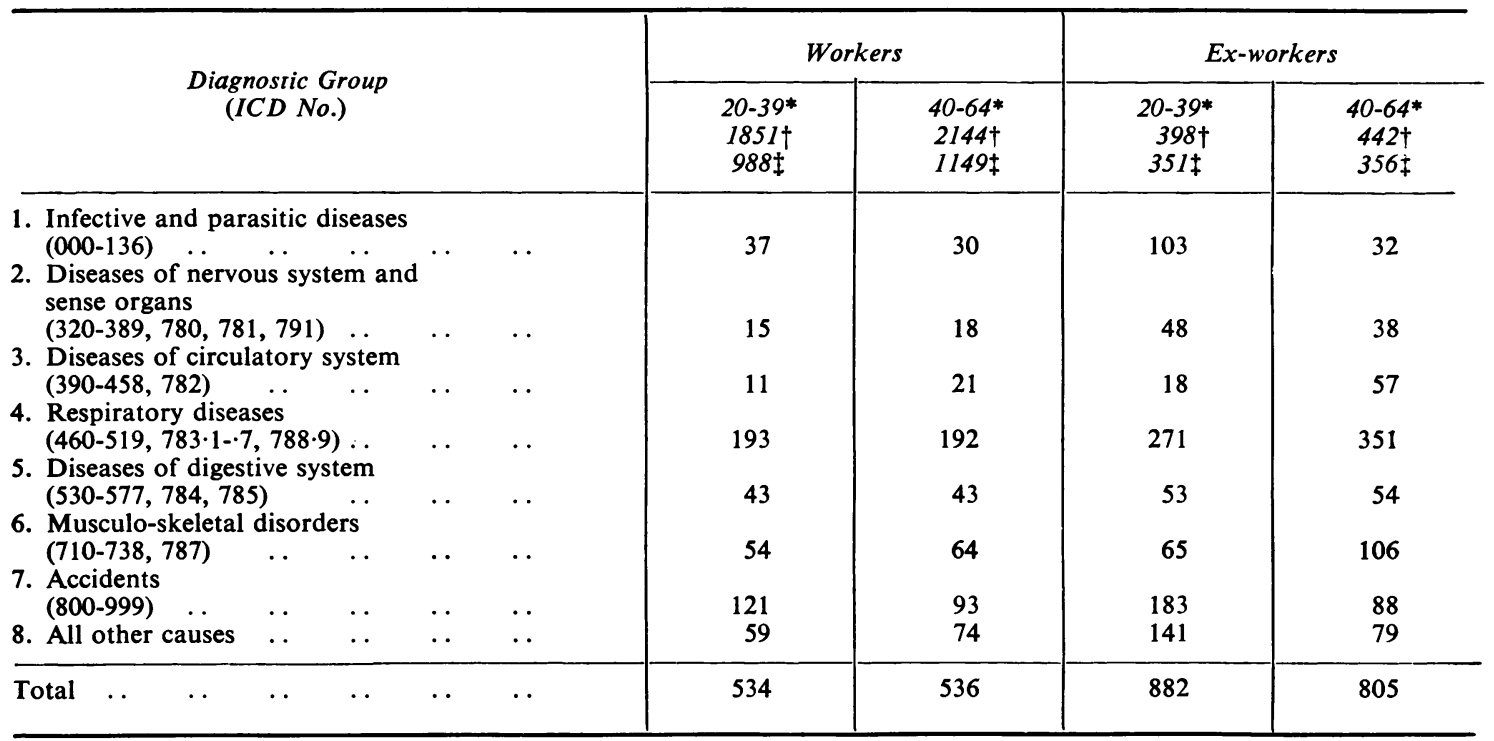

*Age

† Man years at risk

$\ddagger$ Total number of absences

TABLE 4

Numbers of SPELls and Rates

(SPells/1000 Man Years) Of All AbSences BY EXPOSURE CATEGORY FOR WORKERS AND EX-WORKERS

\begin{tabular}{ll|c|c|c|c}
\hline \multirow{2}{*}{\multicolumn{2}{c|}{}} & \multicolumn{2}{c|}{ Workers } & \multicolumn{2}{c}{ Ex-workers } \\
\cline { 3 - 6 } & & Spells & Rate & Spells & Rate \\
\hline High.. &.. & 336 & 467 & 90 & 796 \\
Mixed &. & 711 & 451 & 190 & 722 \\
Low .. &. & 586 & 657 & 217 & 931 \\
None &.. & 504 & 623 & 210 & 909 \\
& & & & & \\
\hline
\end{tabular}

TABLE 5

Numbers of Spells and Rates

(Spells/1000 Man Years) of Potentially

LEAD-INDUCED ABSENCES BY EXPOSURE

CATEGORY FOR WORKERS AND EX-WORKERS

\begin{tabular}{ll|c|c|c|c}
\hline \multirow{2}{*}{ Exposure } & \multicolumn{2}{c|}{ Workers } & \multicolumn{2}{c}{ Ex-workers } \\
\cline { 3 - 6 } & & Spells & Rate & Spells & Rate \\
\hline High.. &.. & 22 & 31 & 16 & 142 \\
Mixed &. & 47 & 30 & 30 & 114 \\
Low .. &. & 47 & 53 & 13 & 56 \\
None &.. & 43 & 53 & 27 & 117 \\
& & & & & \\
\hline
\end{tabular}

TABLE 6

Percentage of Total Absences Due to

Potentially Lead-INDUCED AbSENCES BY

EXPOSURE FOR WORKERS AND EX-WORKERS

\begin{tabular}{lll|c|c}
\hline \multicolumn{2}{c|}{ Exposure } & Workers & Ex-workers \\
\hline High &. &. & 6.5 & 17.8 \\
Mixed &. &. & 6.6 & 15.8 \\
Low &. &. & 8.0 & 6.0 \\
None &.. &.. & 8.5 & 12.9 \\
& & & & \\
\hline
\end{tabular}

were $7 \cdot 4 \%$ for workers and $12 \cdot 2 \%$ for ex-workers. This difference is highly significant (SND $=3.48$, $P<0.001$ ).

A number of men worked in departments of high exposure and then moved to other departments of lower exposure. If there had been a lead exposure factor in sickness absence there might have been some carry-over effect. Absences after the transfer might have been due to their previous high exposure, thus masking genuine differences between exposure categories. Therefore the absence experience of men who had left high exposure departments was investigated (Table 7). The rates for workers in this group were higher than the overall rates. Had the overall rates applied, the expected number of absences in this group would have been 275 compared with 353 observed. This difference was highly significant 
TABLE 7

Spells and Rates (SPells/1000 Man Years) of All Absences of Men Leaving High EXPOSURE DEPARTMENTS, BY EXPOSURE CATEGORY FOR WORKERS AND EX-WORKERS

\begin{tabular}{|c|c|c|c|c|}
\hline \multirow{3}{*}{ Exposure } & \multirow{2}{*}{\multicolumn{2}{|c|}{$\begin{array}{c}\begin{array}{c}\text { Workers } \\
(130 \text { men })\end{array} \\
474 \text { man years }\end{array}$}} & \multirow{2}{*}{\multicolumn{2}{|c|}{$\begin{array}{c}\begin{array}{c}\text { Ex-workers } \\
(44 \text { men })\end{array} \\
87 \text { man years }\end{array}$}} \\
\hline & & & & \\
\hline & Spells & Rate & Spells & Rate \\
\hline $\begin{array}{l}\text { Mixed } \\
\text { Low .. } \\
\text { None }\end{array}$ & $\begin{array}{r}88 \\
152 \\
113\end{array}$ & $\begin{array}{l}561 \\
779 \\
926\end{array}$ & $\begin{array}{l}23 \\
32 \\
15\end{array}$ & $\begin{array}{r}697 \\
1000 \\
682\end{array}$ \\
\hline
\end{tabular}

$\left(\chi_{(1)}^{2}=21 \cdot 6\right)$ and most noticeable in the non-exposed departments. For ex-workers the rates were very similar to the overall rates, and indeed not significantly different $\left(\chi_{(1)}^{2}=0 \cdot 18\right)$.

A similar analysis was performed for absences due to the potentially lead-induced causes. Applying the overall rates, the expected number of such absences for workers in this group was $21 \cdot 6$ compared with 31 observed. The difference was significant $\left(\chi_{(1)}^{2}=4.09\right.$, $P<0.05)$. The corresponding figures for ex-workers were 5 observed and 8.2 expected, the difference being non-significant $\left(\chi_{(1)}^{2}=1 \cdot 25\right)$.

There was thus some evidence of a carry-over effect for men who had worked in high exposure departments and had transferred to lower exposure areas. However, further analysis showed that allowing for this did not alter the patterns already found. There was no similar effect for men moving from no or low exposure departments to higher exposure areas.

Table 8 shows the numbers of men and the man years at risk in each blood lead category for workers

TABLE 8

Numbers of Men and Man Years at RisK BY BLOOD LEAD CATEGORY FOR WORKERS AND EX-WORKERS

\begin{tabular}{c|c|c|c|c}
\hline \multirow{2}{*}{$\begin{array}{c}\text { Mean } \\
\text { blood lead }\end{array}$} & \multicolumn{2}{|c|}{ Workers } & \multicolumn{2}{c}{ Ex-workers } \\
\cline { 2 - 5 } \cline { 2 - 4 } & No. & $\begin{array}{c}\text { Man- } \\
\text { years }\end{array}$ & No. & $\begin{array}{c}\text { Man- } \\
\text { years }\end{array}$ \\
\hline $\begin{array}{c}\text { None } \\
<2.41 \mu \mathrm{mol} / 1\end{array}$ & 152 & 978 & 226 & 427 \\
$\begin{array}{c}(50 \mu \mathrm{g} / 100 \mathrm{ml}) \\
\geqslant 2.41 \mu \mathrm{mol} / 1\end{array}$ & 287 & 1872 & 64 & 227 \\
$(50 \mu \mathrm{g} / 100 \mathrm{ml})$ & 176 & 1145 & 50 & 186 \\
\hline
\end{tabular}

and ex-workers. A far smaller percentage of exworkers had blood lead levels measured, although for those who did, the percentage of those with levels lower than $2.41 \mu \mathrm{mol} / 1(50 \mu \mathrm{g} / 100 \mathrm{ml})$ was similar to that for workers $(56.2 \%$ and $62.0 \%$ respectively).

Table 9 shows the number of spells and rates of all absences by blood lead category for workers and ex-

TABLE 9

Numbers OF SPELls aNd Rates

(Spells/1000 Man Years) of All Absences BY BLOOD LEAD CATEGORY FOR WORKERS AND EX-WORKERS

\begin{tabular}{c|c|c|c|c}
\hline \multirow{2}{*}{$\begin{array}{c}\text { Mean } \\
\text { blood lead }\end{array}$} & \multicolumn{2}{|c|}{ Workers } & \multicolumn{2}{c}{ Ex-workers } \\
\cline { 2 - 5 } & $\begin{array}{c}\text { No. } \\
\text { spells }\end{array}$ & Rate & $\begin{array}{c}\text { No. } \\
\text { spells }\end{array}$ & Rate \\
\hline $\begin{array}{c}\text { None } \quad . \\
<2.41 \mu \mathrm{mol} / 1\end{array}$ & 526 & 538 & 398 & 932 \\
$\begin{array}{c}(50 \mu \mathrm{g} / 100 \mathrm{ml}) \\
\geqslant 2.41 \mu \mathrm{mol} / 1\end{array}$ & 1017 & 543 & 172 & 758 \\
$(50 \mu \mathrm{g} / 100 \mathrm{ml})$ & 594 & 519 & 137 & 737 \\
\hline
\end{tabular}

workers. The rates of absences were very similar for those men with mean blood lead levels lower than $2 \cdot 41$ $\mu \mathrm{mol} / \mathrm{l}$ and for those men with blood lead higher than or equal to $2.41 \mu \mathrm{mol} / \mathrm{l}$ in both workers and exworkers. For workers the lower blood lead group had a slightly higher rate of absence (543 spells/1000 man years against 519), while for ex-workers the higher blood lead group's rate was slightly greater (737 spells/1000 man years against 758 ). Neither of these differences is significant.

A similar assessment was made for absences due to potentially lead-induced causes (Table 10). The

\section{TABLE 10}

Numbers of SPells aNd Rates

(SPELls/1000 MAN Years) OF

POTENTIALly LEAD-INDUCED

Absences by Blood Lead Category for WORKERS AND EX-WORKERS

\begin{tabular}{l|c|c|c|c}
\hline \multirow{2}{*}{$\begin{array}{c}\text { Mean } \\
\text { blood lead }\end{array}$} & \multicolumn{2}{|c|}{ Workers } & \multicolumn{2}{|c}{ Ex-workers } \\
\cline { 2 - 5 } & $\begin{array}{c}\text { No. } \\
\text { spells }\end{array}$ & Rate & $\begin{array}{c}\text { No. } \\
\text { spells }\end{array}$ & Rate \\
\hline $\begin{array}{l}\text { None } \ldots . \\
<2.41 \mu \mathrm{mol} / 1\end{array}$ & 46 & 43 & 49 & 115 \\
$(50 \mu \mathrm{g} / 100 \mathrm{ml})$ & 66 & 35 & 19 & 84 \\
$\geqslant 2 \cdot 41 \mu \mathrm{mol} / 1$ & 47 & 41 & 18 & 97 \\
\hline$(50 \mu \mathrm{g} / 100 \mathrm{ml})$ & 47 & & & \\
\hline
\end{tabular}

group with mean blood lead levels of $2.41 \mu \mathrm{mol} / 1$ or higher was absent more often than the group with 
mean blood lead levels lower than 2.41 for both workers and ex-workers. However these differences are not significant.

The percentages of total absences due to potentially lead-induced absences by blood lead category were considered (Table 11). The higher mean blood

TABLE 11

Percentage of Total Absences due to Potentially Lead-Induced Absences by BLOOD LEAD CATEGORY FOR WORKERS AND EX-WORKERS

\begin{tabular}{|c|c|c|}
\hline $\begin{array}{c}\text { Mean } \\
\text { blood lead }\end{array}$ & Workers & Ex-workers \\
\hline $\begin{array}{l}\text { None } \ldots \\
<2.41 \mu \mathrm{mol} / 1 \\
(50 \mu \mathrm{g} / 100 \mathrm{ml}) \\
\geqslant 2.41 \mu \mathrm{mol} / 1 \\
(50 \mu \mathrm{g} / 100 \mathrm{ml})\end{array}$ & $\begin{array}{r}8.7 \\
6.5 \\
7.9\end{array}$ & $\begin{array}{l}12 \cdot 3 \\
11 \cdot 0 \\
13 \cdot 1\end{array}$ \\
\hline
\end{tabular}

lead group had slightly larger percentages than the lower mean blood lead group for both workers and ex-workers. However neither difference is significant.

The lengths of absences, in working days, were also examined. (Tables 12, 13). Such data are diffi-

TABLE 12

Mean Lengths of All Absences (Working Days/SPELL) BY EXPOSURE CATEGORY FOR WORKERS AND EX-WORKERS

\begin{tabular}{lll|c|c}
\hline \multicolumn{2}{c|}{ Exposure } & Workers & Ex-workers \\
\hline High &. &. & 17.0 & $15 \cdot 0$ \\
Mixed &. &. & 18.6 & $18 \cdot 2$ \\
Low &. &. & 18.9 & 24.9 \\
None &. &. & 15.6 & 19.8 \\
& & & & \\
\hline
\end{tabular}

TABLE 13

Mean Lengths of Potentially LeadINDUCED ABSENCES (WoRking DAYS/SPELL) BY EXPOSURE CATEGORY FOR WORKERS AND EX-WORKERS

\begin{tabular}{lll|c|c}
\hline \multicolumn{2}{c|}{ Exposure } & & Workers & Ex-workers \\
\hline High &. &. & $11 \cdot 7$ & $7 \cdot 8$ \\
Mixed &. &. & 18.4 & $15 \cdot 3$ \\
Low &. &. & $17 \cdot 3$ & 34.9 \\
None &. &. & 10.9 & 27.6 \\
\hline
\end{tabular}

cult to analyse since they are skewed, but there did not appear to be any effect of exposure either for workers or ex-workers. This applied to all absences and potentially lead-induced absences.
The two highest values in the tables, 34.9 and 27.6 for the mean lengths of potentially lead-induced absences in ex-workers for the low and no exposure groups respectively, occurred when the mean of a small number of observations was biased by one very large value.

\section{Discussion}

Many factors, apart from disease, are known to influence sickness absence (Taylor and Pocock, 1973). Imperfections in the present data include lack of controls for shift work, type of job, hourly wages, attitudes of supervisors, inaccurate diagnosis, and so on. However, it is not thought that these would introduce significant bias in favour of the more highly exposed workers. In particular, high exposure has never been rewarded financially. The effects of length of service and job satisfaction probably account for the higher rates of absence in ex-workers (Taylor and Pocock, 1973), although the higher percentage of absences due to the selected causes in this group is difficult to explain.

It may possibly be accounted for if we consider the study by Whitehead (1971) which showed that the 'symptoms and ill-defined causes' group of absences (which overlaps with the potentially leadinduced absences) had risen at a greater rate than the increase in certified absence. Thus where absence was high, the proportion of absences due to these causes was higher. Nevertheless, the significantly greater proportions of potentially lead-induced absences among ex-workers in the high and mixed exposure groups (as opposed to the low and no exposure groups) could be interpreted as showing that such exposure is a cause of increased sickness absence in these men.

Also puzzling is the apparent carry-over effect after working in high exposure departments. This suggests that men affected by lead move to less exposed departments (temporary changes are usually involuntary, while permanent transfers tend to be voluntary). However, even when allowance is made for such effect, the highly exposed departments do not have higher sickness absence, so whether the carry-over effect is genuine is dubious. It seems unlikely that any such effect is related to changing departments since there is no comparable increased absence among men who have moved from lower to higher exposure departments. Because of the low numbers and skewness of the sickness absence data, too much importance should not be placed on the $\chi^{2}$ tests (Taylor and Pocock, 1973). Indeed, some of the inconsistent or puzzling findings may have arisen because of the low numbers.

The mass media have lately shown interest in the adverse effects of lead exposure, although much of this concern has been focused on children. 
Accurate knowledge of the level at which the general population becomes at risk of subclinical lead poisoning will depend ultimately on studies of many groups such as the old, the sick, the young and the underprivileged, as well as normal adult males. The present study appears to show little evidence of harmful effects of lead exposure as measured by sickness absence in men with blood lead levels of up to $3.86 \mu \mathrm{mol} / \mathrm{l}(80 \mu \mathrm{g} / 100 \mathrm{ml})$.

We thank the Directors of Chloride Automotive Batteries Limited for permission to undertake this study, and the Personnel and Medical Departments, especially Sister Ann Willetts, for much assistance.

\section{References}

Dingwall-Fordyce, I. and Lane, R. E. (1963). A follow-up study of lead workers. British Journal of Industrial Medicine, 20, 313-315.

Hoschek, R. and Schittke, H. J. (1973). Vergleichs Bestimmungen für Bleim Blut sowie für Blei und Kadmium in Urin. Dortmund-Forschungsbericht Nr. 101.

Lane, R. E., et al. (1968). Diagnosis of inorganic lead poisoning: a statement. British Medical Journal, 4, 501.
Malcolm, D. (1971). Prevention of long-term sequelae following the absorption of lead. Archives of Environmental Health, 23, 292-298.

National Academy of Sciences (1972). Airborne lead in perspective. In Report by the Committee on Biologic Effects of Atmospheric Pollutants, pp. 88-89. National Academy of Sciences, Washington, D.C.

Tabershaw-Cooper Associates Inc. (1974). Health Study of Lead Workers: Final Report. 2180 Milvia Street, Berkeley, California 94704.

Taylor, P. J. and Pocock, S. J. (1973). Sickness absence. In Occupational Health Practice, edited by R. S. F. Schilling, ch. 10, p. 220. Butterworths, London.

Waldron, H. A. and Stöfen, D. (1974). Subclinical Lead Poisoning, pp. 91 et seq. Academic Press, London.

Whitehead, F. E. (1971). Trends in Certificated Sickness Absence. Social Trends No. 2. HMSO, London.

Williams, M. K., King, E., and Walford, Joan (1969). An investigation of lead absorption in an electric accumulator factory with the use of personal samplers. British Journal of Industrial Medicine, 26, 202-216.

World Health Organization (1967). International Classification of Diseases. WHO, Geneva.

Received for publication 28 October 1975

Accepted for publication 16 January 1976 